\title{
Study of Characteristics of Surface Subsidence in Longwall Coal Mine under Poor Ground Conditions in Indonesia
}

\author{
Phanthoudeth Pongpanya ${ }^{1,2}$, Takashi Sasaoka ${ }^{1}$, Hideki Shimada ${ }^{1} \&$ Sugeng Wahyudi $^{1}$ \\ ${ }^{1}$ Department of Earth Resources Engineering, Kyushu University, Fukuoka, Japan \\ 2 Department of Mining Engineering, National University of Laos, Vientiane, Laos \\ Correspondence: Phanthoudeth Pongpanya, Department of Earth Resources Engineering, Kyushu University, \\ Fukuoka 819-0395, Japan. Tel: 81-80-5602-9395. E-mail: pongpanya15r@mine.kyushu-u.ac.jp
}

Received: April 24, 2016

doi:10.5539/esr.v6n1p129
Accepted: January 11, 2017

Online Published: January 31, 2017

\begin{abstract}
This paper aims to study the characteristics of surface subsidence induced by longwall mining under poor ground conditions in Indonesia by means of numerical simulation techniques using finite difference code "FLAC3D". The effect of mining depth in cases of single panel and multi-panel longwall mining, the influence of panel and pillar widths, and the impact of backfilling material, were incorporated into the FLAC3D software. The simulated results indicated that the angle of draw and maximum surface subsidence were significantly associated with the depth of mining, the number of extracted panels, the width of panel and pillar, and the type of backfill. In single panel mining, the largest maximum surface subsidence is observed in case of the shallowest mining depth, and it gradually decreases as the depth increases. In contrast, the angle of draw increases with increasing the mining depth. In multi-panel mining, the angle of draw and maximum surface subsidence increase as the mining depth increases. Moreover, the angle of draw and maximum surface subsidence decrease when the narrow panel and large pillar widths are adopted, and the backfilling materials are applied.
\end{abstract}

Keywords: surface subsidence, longwall coal mining, poor ground conditions, numerical simulation, FLAC3D

\section{Introduction}

Coal has been used as fuel in many major industrial sectors, such as electricity generation, steel and cement productions, and other manufacturing activities. Indonesia is one of the world's largest coal producers and exporters. The coal production of Indonesia has increased significantly in the past years (Figure 1). Indonesia exports the coal between $70 \%-80 \%$ of total coal production to China and India, and the remaining is consumed in domestic markets (http://www.indonesia-investments.com/business/commodities/coal/item236, 2016). The coal production in Indonesia is mainly from the surface mining method. Recently, many surface mines have been stopped their operations due to an increase of the stripping ratio as the mining depth increased. The environmental impacts and protections have challenged the new development of surface mining, especially where the coal seams are located beneath agricultural areas, protected forests, and man-made structures. As a result, some underground mines have been being developed and operated in order to meet the increased demands of coal production in the country (Takamoto et al., 2014; Sasaoka et al., 2014). A longwall mining is the most popular coal extracting technique by underground mining in Indonesia.

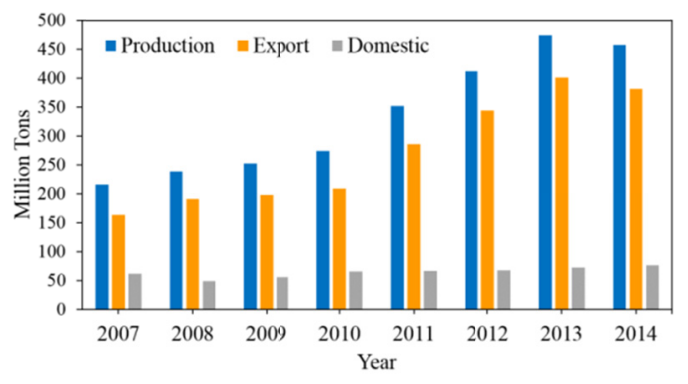

Figure 1. Production, export, and domestic consumption of Indonesian coal (http://www.indonesia-investments.com/business/commodities/coal/item236, 2016) 
Longwall mining is a highly productive, efficient, and safe underground mining method, which applies to extract the coal seams of relatively large horizontal extent and uniform thickness (Whittaker \& Reddish, 1989; Brady \& Brown, 2004). Peng and Chiang (1984) demonstrated the mechanisms of roof strata movement above a longwall mining (Figure 2). The roof strata behind the excavation face are collapsed to fill the stope void when a longwall panel of sufficient width and length is mined, resulting in subsiding of the immediate roof strata toward the surface. Whittaker and Reddish (1989) illustrated the basic subsidence profile resulting from longwall mining of a single panel (Figure 3). Two parameters are used to define the magnitude, shape, and limitation of the subsidence at the surface, such as maximum surface subsidence $\left(\mathrm{S}_{\max }\right)$ and angle of draw $(A o D)$.

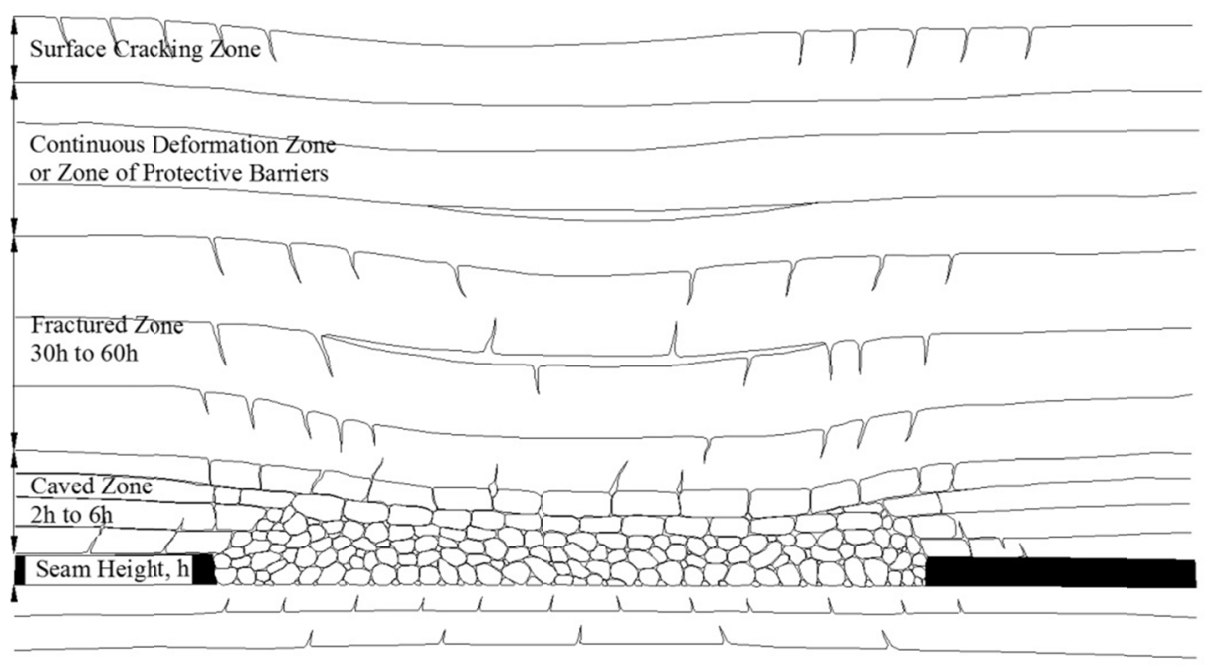

Figure 2. Strata movement resulting from longwall mining (Peng, \& Chiang, 1984)

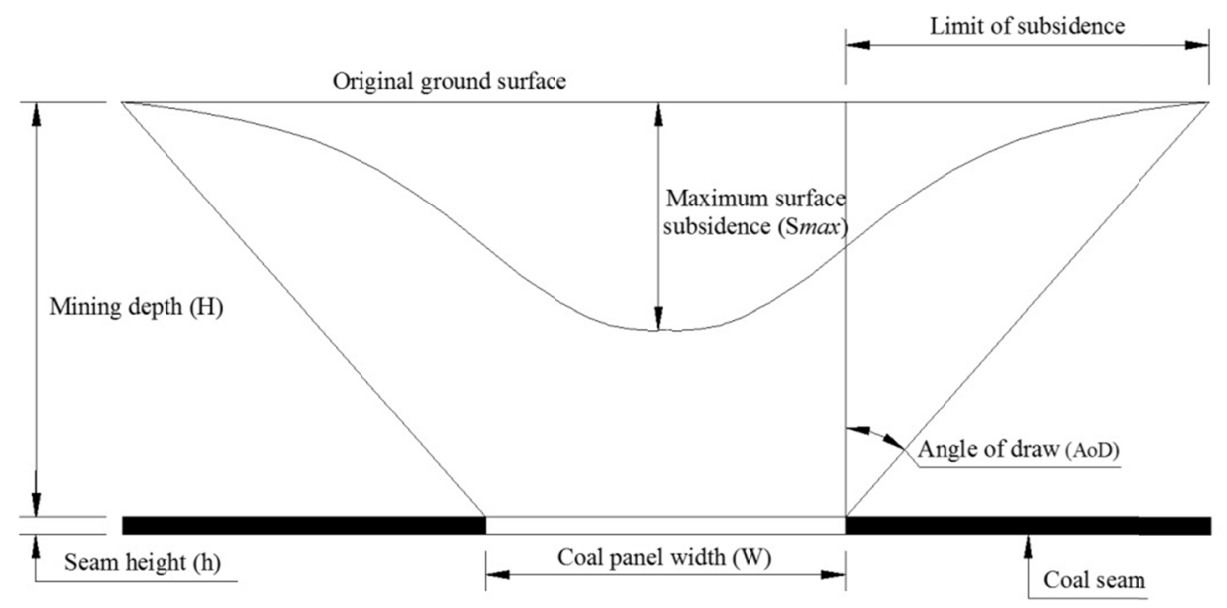

Figure 3. Basic subsidence profile above single longwall mining (Whittaker, \& Reddish, 1989)

In Indonesia, the coal measure strata generally consist of sedimentary rocks such as mudstone, claystone, sandstone, and siltstone. Results of uniaxial compressive strength (UCS) tests indicated that the strengths of rocks in Indonesian coal mines are very weak. The UCS values of coal measure rocks range from 1-20 MPa (Sasaoka et al., 2007; Garcia, Altounyan, Nitaramorn, \& Lewis, 2010; Sasaoka et al., 2014; Sasaoka et al., 2015a; Sasaoka et al., 2015b). Because of a large extent of coal is removed from the seam, and due to the coal measure rocks are weak, a large subsidence at the surface can be expected when a longwall mining is applied in Indonesian underground coal mine. A study of surface subsidence is needed in order to avoid the adverse impacts of subsidence at the surface. The knowledge improves a design of longwall mining. Numerous researches have been conducted to predict the surface subsidence in longwall coal mines. However, most researches have been 
carried out at the mine sites where the rock strengths are medium to strong (Keilich, Seedsman, \& Aziz, 2006; Zhang, Mitra, \& Hebblewhite, 2006; Xu et al., 2013), only few researches have been carried out at the mine sites where the rocks are weak (Takamoto et al., 2014; Sasaoka et al., 2015b). Therefore, the understanding of surface subsidence in poor ground conditions has still been limited.

The objective of this research was to study the characteristics of surface subsidence induced by longwall mining under poor ground conditions in Indonesia. The effect of single panel and multi-panel mining at various depths, the influence of longwall panel and pillar widths, and the impact of backfill materials, were studied by means of numerical simulation using a three dimensional finite difference code "FLAC3D". The angle of draw (AoD) and maximum surface subsidence $\left(\mathrm{S}_{\max }\right)$ were used to describe the characteristics of subsidence at the surface.

\section{Method}

The characteristics of surface subsidence were studied numerically using a three dimensional finite difference code "FLAC3D". FLAC3D is a numerical software which is widely used for analyzing stress and deformation around surface and underground openings conducted in both soil and rock. The software utilizes an explicit finite-difference formulation that can model complex behaviors of three-dimensional geomechanical problems (http://www.itascacg.com/software/flac3d, 2017). Effects of various mining conditions were considered in this study. Several models were constructed for numerical simulations. The models were $1330 \mathrm{~m}$ in width, $2000 \mathrm{~m}$ in length, and with various heights depending upon the mining depths. An example of a $200 \mathrm{~m}$ mining depth model is illustrated in Figure 4. The bottom of the model was fixed in the vertical direction, the sides were fixed in the horizontal direction, and the surface was set free in all directions. The vertical stress component was modeled as a function of overburden thickness or mining depth $\left(\mathrm{P}_{\mathrm{v}}=\gamma \mathrm{H}, \gamma\right.$ is unit weight of overburden, and $\mathrm{H}$ is overburden thickness) (Hoek \& Brown, 1980; Hoek, Kaiser, \& Bawden, 1993; Hoek, 2006), while the horizontal stress component was assumed to be equal to the vertical stress. The elasto-plastic Mohr-Coulomb criterion was used as a failure criterion throughout the analyses. The typical properties of Indonesian coal measure rocks and coal seam (PT Gerbang Daya Mandiri [PTGDM], 2010), The properties of goaf (Thin, Pine, \& Trueman, 1993; Xie, Chen, \& Wang, 1999; Yasiti \& Unver, 2005), and the properties of backfilling materials (Wang, Poulsen, Shen, Xue, \& Jiang, 2011; Choudhary, 2013), are summarized in Table 1. In simulation, a coal panel was extracted step by step. After the excavation face moved forward, the caved area behind the coal face was filled by a very soft goaf material. The excavation steps were repeated until the coal panel was entirely extracted.

Table 1. Properties of materials used in simulations

\begin{tabular}{lccccc}
\hline \multirow{2}{*}{ Parameter } & \multirow{2}{*}{ Rock mass } & Coal seam & \multirow{2}{*}{ Goaf } & \multicolumn{2}{c}{ Backfill } \\
\cline { 5 - 6 } \cline { 5 - 6 } & & & Non-cohesive & Cohesive \\
\hline Uniaxial compressive strength $(\mathrm{MPa})$ & 10.37 & 8.16 & - & - & 1.00 \\
Density $\left(\mathrm{kg} / \mathrm{m}^{3}\right)$ & 2140 & 1380 & 1700 & 1100 & 1277 \\
Young's modulus $(\mathrm{MPa})$ & 2324 & 1295 & 15 & 20 & 185 \\
Poisson's ratio & 0.27 & 0.32 & 0.25 & 0.15 & 0.36 \\
Friction angle $\left({ }^{\circ}\right)$ & 38 & 45 & 25 & - & 27 \\
Cohesion $(\mathrm{MPa})$ & 0.540 & 2.630 & 0.001 & - & 0.574 \\
Tensile strength $(\mathrm{MPa})$ & 0.10 & 0.10 & - & - & 0.15 \\
\hline
\end{tabular}

Firstly, the paper investigated the effect of mining depth on surface subsidence in cases of single and multi-panel longwall mining. The mining depth was changed ranging from $50 \mathrm{~m}$ to $200 \mathrm{~m}$. Only one panel was considered in single panel mining simulation (Figure $5 \mathrm{a}$ ), while three panels were considered in multi-panel mining simulation (Figure $5 \mathrm{~b}$ ). A coal panel was $130 \mathrm{~m}$ in width, $1000 \mathrm{~m}$ in length, and $3 \mathrm{~m}$ in thickness. The panels were separated by a $30 \mathrm{~m}$ wide pillar in case of multi-panel mining. Secondly, the effect of panel width was studied in the paper. The model included three longwall panels. The panel widths of $70 \mathrm{~m}, 100 \mathrm{~m}$, and $130 \mathrm{~m}$, were simulated in the simulations (Figure $5 \mathrm{c}$ ). The pillar between the panels was $30 \mathrm{~m}$ width, and the mining depth was $200 \mathrm{~m}$ in this case. Thirdly, the influence of pillar width on surface subsidence was analyzed and discussed. The numerical simulation considered four pillar widths, such as $30 \mathrm{~m}, 40 \mathrm{~m}, 50 \mathrm{~m}$, and $60 \mathrm{~m}$ (Figure $5 \mathrm{~d}$ ). The model consisted of three longwall panels. The panel width and the mining depth, was $130 \mathrm{~m}$ and $200 \mathrm{~m}$, respectively. Lastly, the impact of backfilling material was investigated in this paper. Two types of backfills, such as non-cohesive and cohesive backfills, were simulated numerically. Three longwall panels were included in the model. The panel width of $130 \mathrm{~m}$ width, the pillar width of $30 \mathrm{~m}$, and the mining depth of $200 \mathrm{~m}$, were considered in the simulations. Similarly to the goaf modelling, the backfill was filled behind the coal face after 
the excavation face moved forward (Figure 6).

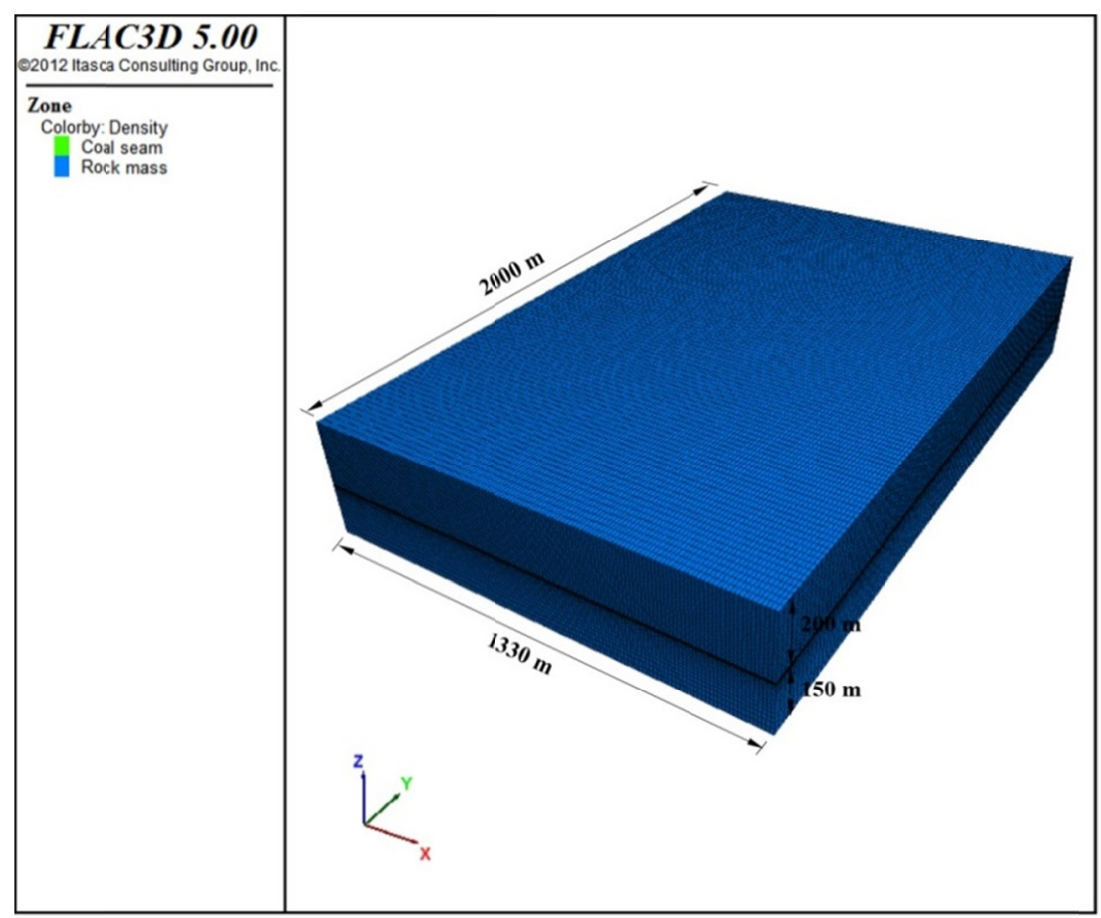

Figure 4. Model geometries of subsidence simulation at $200 \mathrm{~m}$ mining depth

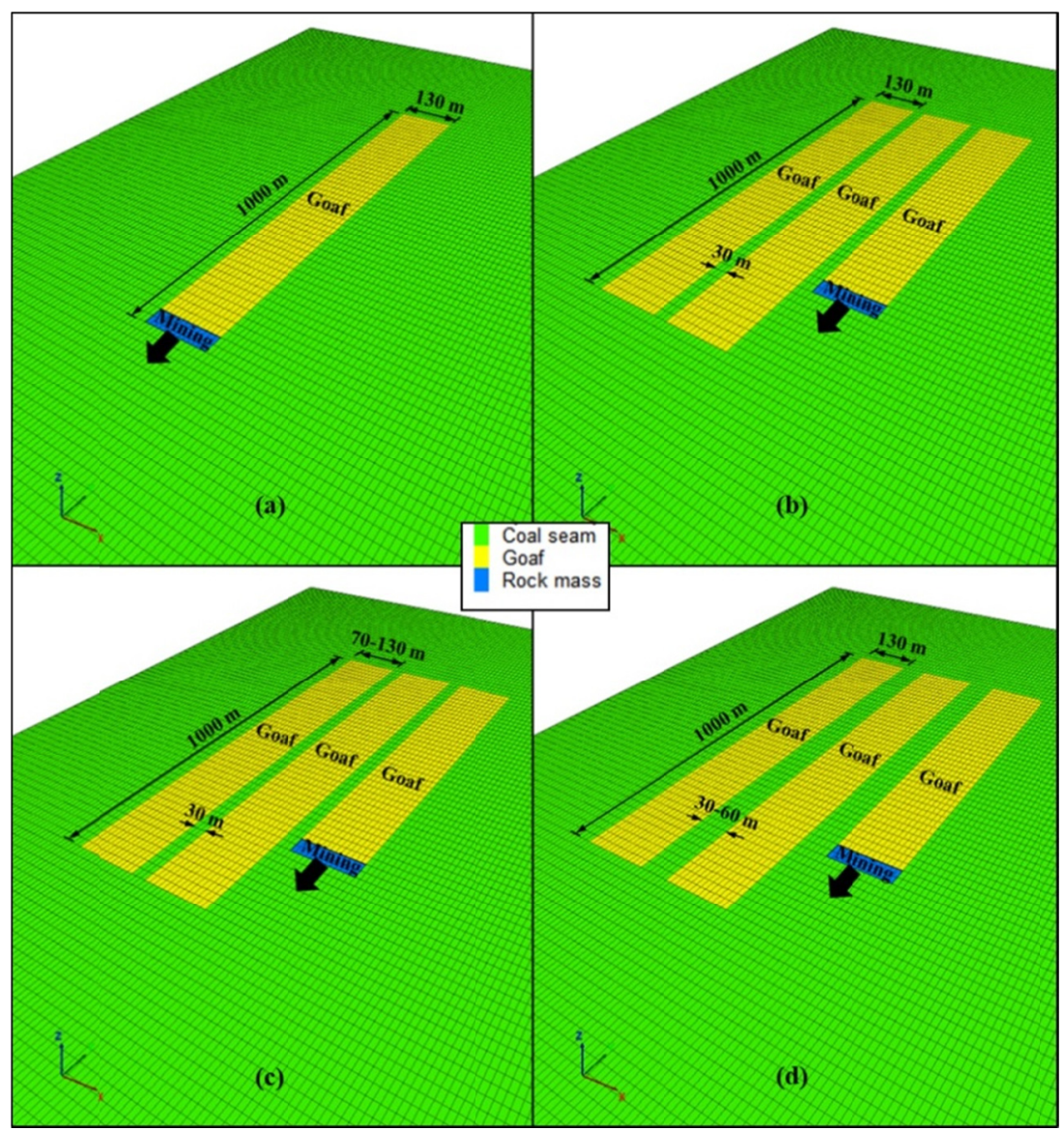

Figure 5. Surface subsidence models for different mining conditions (a) single panel mining (b) multi-panel mining (c) effect of panel width (d) influence of pillar width 


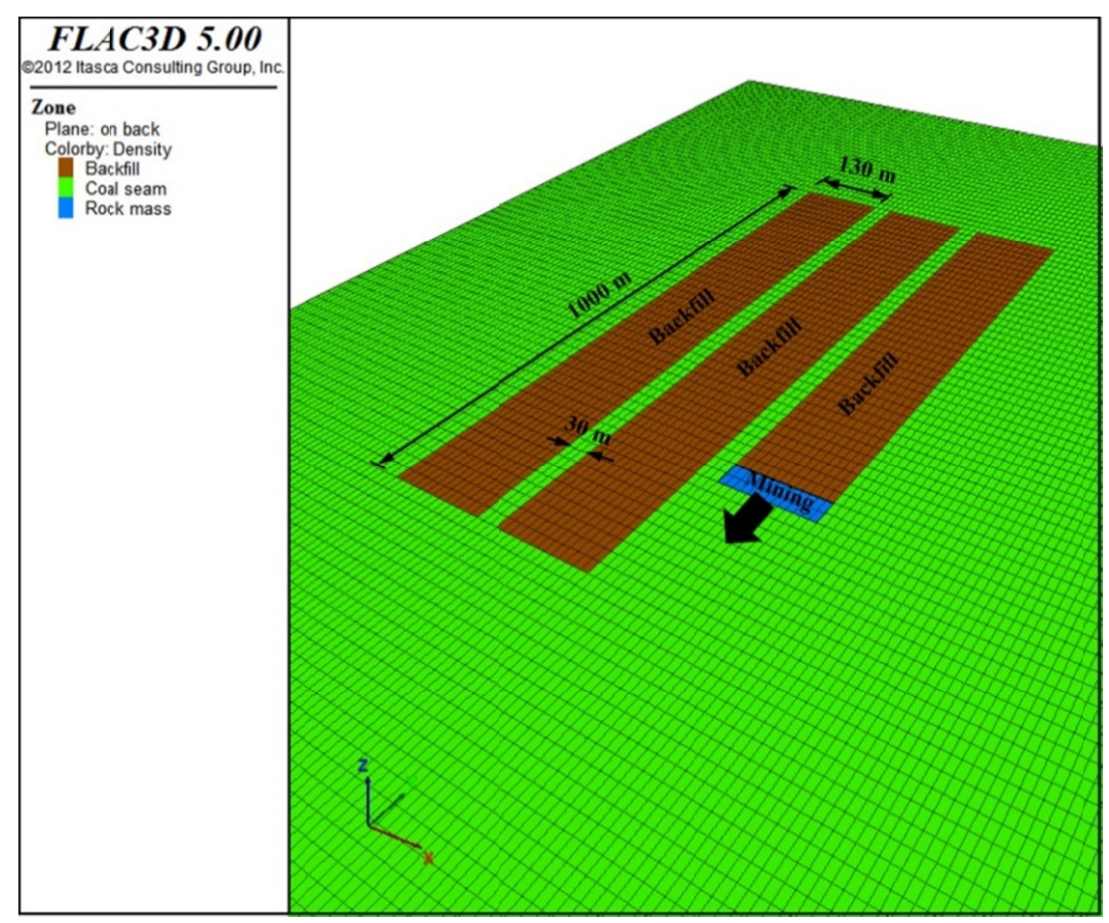

Figure 6. Surface subsidence model for impact of backfilling material application

\section{Results and Discussion}

In longwall mining, the magnitude of surface subsidence is normally less than the thickness of extracted coal seam, due to some voids have been left within the goaf. Many factors affect the extent of surface subsidence such as rock mass strength, panel and pillar widths, and mining depth. In this study, the surface subsidences induced by various longwall mining conditions were analyzed and discussed. AoD and $S_{\max }$ were used to describe the characteristics of surface subsidence. $S_{\max }$ is defined as the maximum extent of settlement at the surface, which occurred above mined-out panels. AoD is defined as an angle between the vertical line above an extraction edge and the inclined line joining the extraction edge with the edge of the subsidence trough (Figure 3 ). AoD is commonly used as a subsidence engineering term to determine the limit of subsidence trough at the surface. The surface subsidence of less than $2 \mathrm{~cm}$ is generally accepted as a value that have no effect on any man-made structures and surface environments. This value is normally adopted as the cut-off point for determination of the AoD (Cohen, et al., 2007; Mine Subsidence Engineering Consultants [MSEC], 2007; Independent Expert Scientific Committee [IESC], 2015). In this research, therefore, the surface subsidence of 2 $\mathrm{cm}$ was used as a cut-off point to calculate the AoD value. The results presented in the following sections were taken from the model centers and expressed in cross-sections.

\subsection{Effect of Mining Depth on Surface Subsidence Characteristics in Case of Single Panel Longwall Mining}

Figure 7 a shows the subsidence contours and the AoD values resulted from single panel mining at various mining depths. A single panel of $30 \mathrm{~m}$ width was adopted, and the mining depths of $50 \mathrm{~m}, 100 \mathrm{~m}, 150 \mathrm{~m}$, and 200 $\mathrm{m}$, were modeled. In all cases of mining depths, the largest subsidence was occurred directly above the mined-out panel, and its magnitude gradually reduced toward the surface. Based on the simulation results, it was found that the degree of AoD was significantly associated with the mining depth. The AoD increased with increasing the depth of mining. This means that when the longwall mining is developed at the deeper site, the larger subsidence area at the surface will be generated. The AoD in case of $50 \mathrm{~m}, 100 \mathrm{~m}, 150 \mathrm{~m}$, and $200 \mathrm{~m}$ mining depth, was $3^{\circ}, 14^{\circ}, 38^{\circ}$, and $53^{\circ}$, respectively.

The data of subsidence contours were plotted into the graph in order to see subsidence profiles (Figure $7 \mathrm{~b}$ ). From the subsidence profiles, the $S_{\max }$ in each case of mining depth was then determined. The largest $S_{\max }$ was observed in case of a $50 \mathrm{~m}$ mining depth, while its magnitude gradually decreased as the mining depth increased. This happened due to a bridging ability of overburden strata over the mined-out panel. The highest panel width to mining depth ratio $(\mathrm{W} / \mathrm{H})$ was happened at a $50 \mathrm{~m}$ mining depth. In this case, the overburden strata were less able to bridge across the mined-out area, and a larger $S_{\max }$ was occurred. In contrast, as the mining depth 
increased, the $\mathrm{W} / \mathrm{H}$ decreased, the overburden rocks were more able to bridge over the mined-out area by arching between the solid coal supports on each side of the panel, and the magnitude of $S_{\max }$ was reduced. The $S_{\max }$ was $45.50 \%, 43.82 \%, 43.30 \%$, and $34.27 \%$ of the total extracted seam height $(3 \mathrm{~m})$ when the mining depth was $50 \mathrm{~m}$, $100 \mathrm{~m}, 150 \mathrm{~m}$, and $200 \mathrm{~m}$, respectively.
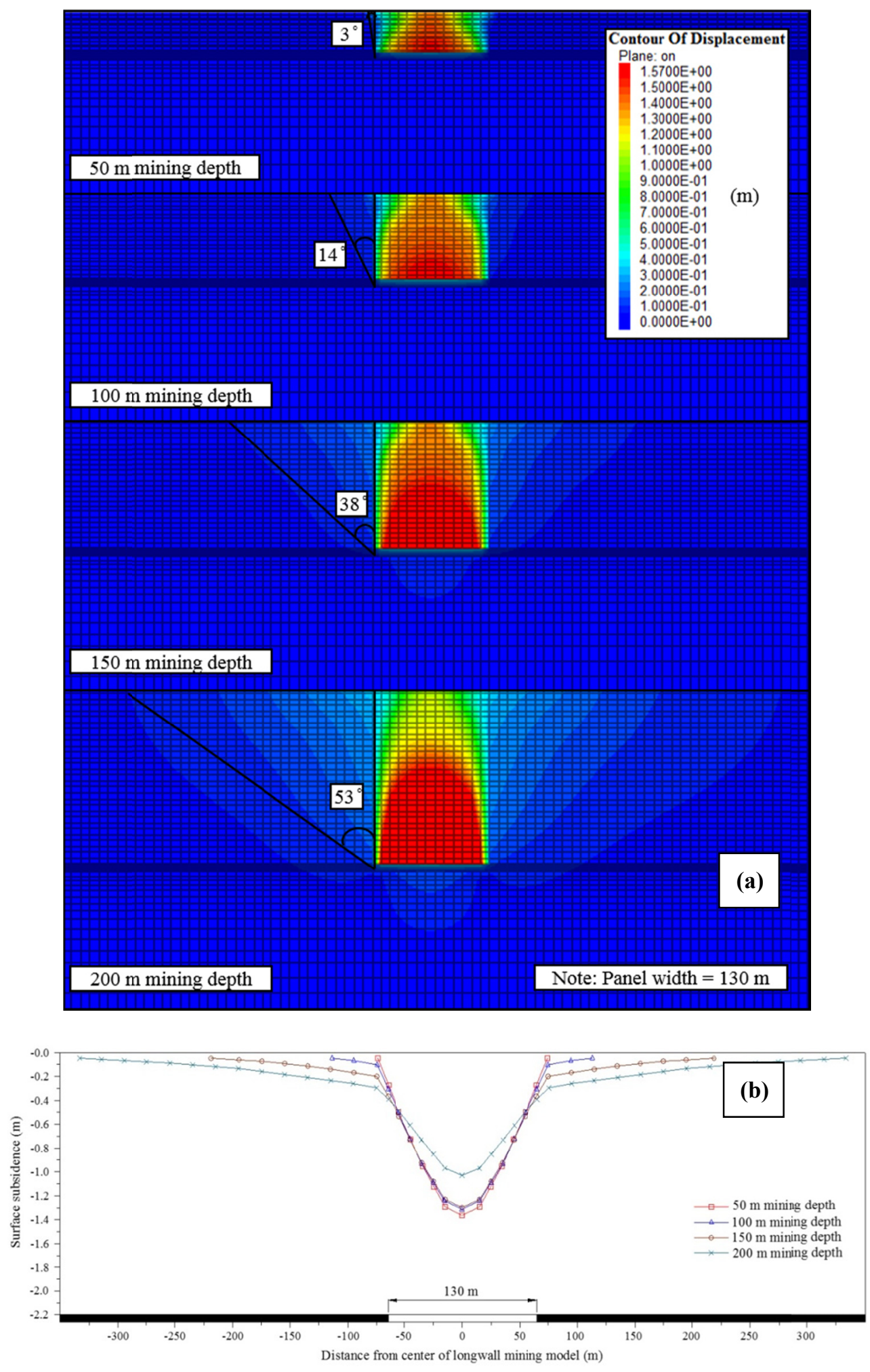

Figure 7. Results of surface subsidence simulation for single panel longwall mining at various mining depths (a) contour of subsidence and angle of draw (b) profile of surface subsidence 


\subsection{Effect of Mining Depth on Surface Subsidence Characteristics in Case of Multi-panel Longwall Mining}

The subsidence contours, AoD values, and subsidence profiles, are shown in Figure 8. A longwall mining of three panels was simulated at four mining depths such as $50 \mathrm{~m}, 100 \mathrm{~m}, 150 \mathrm{~m}$, and $200 \mathrm{~m}$. The panel width of $130 \mathrm{~m}$ and the pillar width of $30 \mathrm{~m}$, were considered in the analyses. The results indicated that the AoD and $\mathrm{S}_{\max }$ increased when several panels were mined in a series, particularly in cases of $100 \mathrm{~m}, 150 \mathrm{~m}$, and $200 \mathrm{~m}$ depths. As the second and subsequent panels were mined, additional subsidence developed over the panel center, and the AoD extended further from the edge of extraction area. This was due to the disturbance within rock strata because of enlarging the mined-out area in an underground.
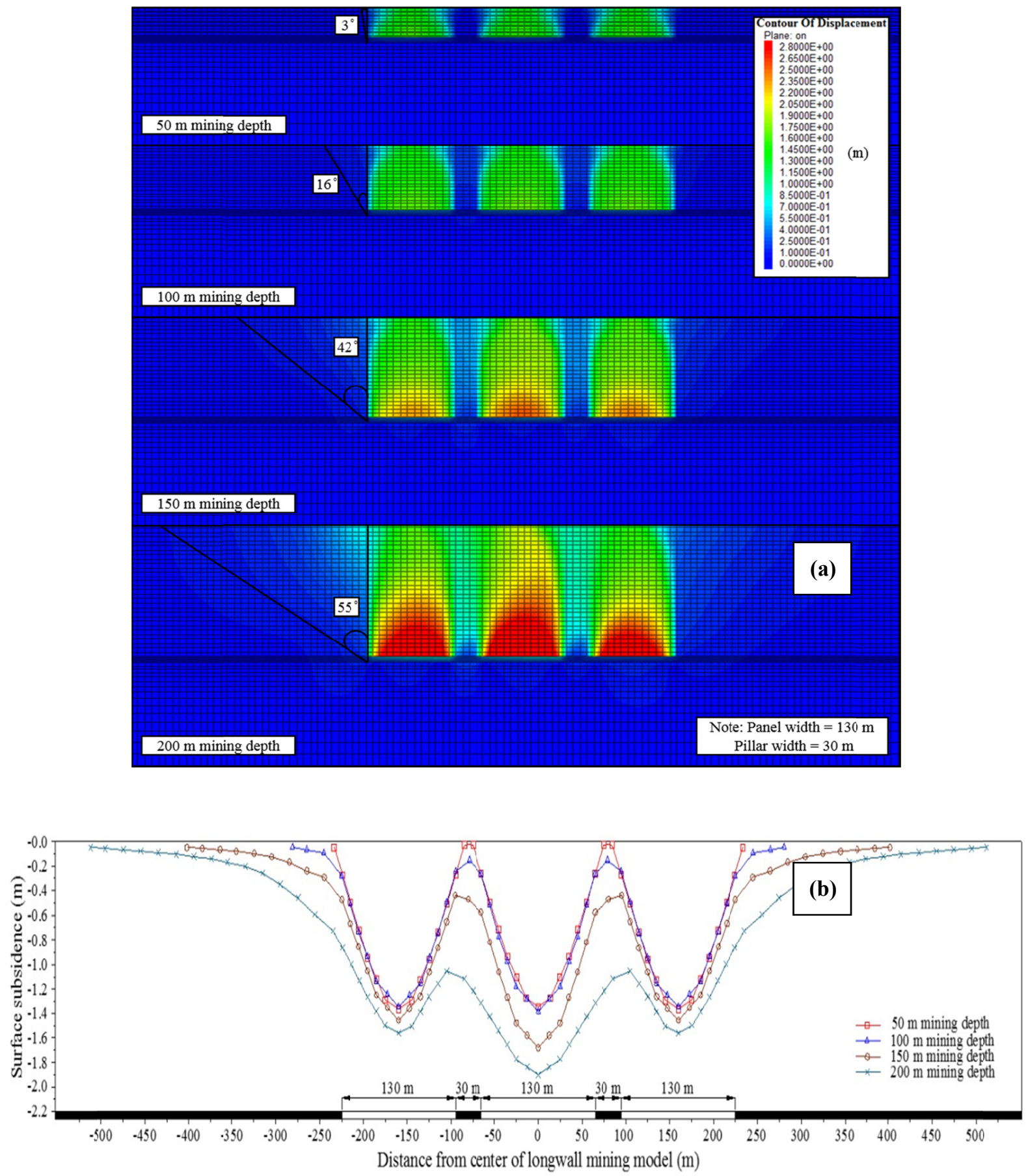

Figure 8. Results of surface subsidence simulation for multi-panel longwall mining at various mining depths (a) contour of subsidence and angle of draw (b) profile of surface subsidence 
From the results, it was observed that the less $A o D$ and $S_{\max }$ were generated after the first panel was mined, while the more $\mathrm{AoD}$ and $\mathrm{S}_{\max }$ were generated after the second and subsequent panels were mined. However, in case of a $50 \mathrm{~m}$ mining depth, the $\mathrm{AoD}$ and $\mathrm{S}_{\max }$ remained unchanged after three panels were mined. The reason of this phenomena can be explained by the ratio of pillar width to mining depth. At a depth of $50 \mathrm{~m}$, the pillar width to mining depth ratio was higher than that of $100 \mathrm{~m}, 150 \mathrm{~m}$, and $200 \mathrm{~m}$ depths. In this case, the pillars provided an adequate amount of support to the rock strata above them. Hence, the developments of additional AoD and $\mathrm{S}_{\max }$ were restricted, and a wavy subsidence profile was produced. On the other hand, as the mining depth increased, the ratio of pillar width to mining depth decreased, the pillars between the panels were less able to support the roof strata. Thus, the magnitudes of AoD and $\mathrm{S}_{\max }$ were increased, and a deeper and smoother subsidence profile was produced. Compared to the single panel mining, the AoD increased from $14^{\circ}, 38^{\circ}$, and $53^{\circ}$ to $16^{\circ}, 42^{\circ}$, and $55^{\circ}$, while the $S_{\max }$ increased from $43.82 \%, 43.30 \%$, and $34.27 \%$ to $46.10 \%, 55.93 \%$, and $63.33 \%$ of the extracted seam thickness, when the mining depth was $100 \mathrm{~m}, 150 \mathrm{~m}$, and $200 \mathrm{~m}$, respectively.

\subsection{Effect of of Panel Width on Characteristics of Surface Subsidence}

In this part of research, the effect of panel width on $A o D$ and $S_{\max }$ was analyzed and discussed. The numerical model included three panels, and various panel widths such as $70 \mathrm{~m}, 100 \mathrm{~m}$, and $130 \mathrm{~m}$, were studied. The pillar width of $30 \mathrm{~m}$ and the mining depth of $200 \mathrm{~m}$, were considered in the simulations. Figure 9 illustrates the AoD and $S_{\max }$ resulted from mining of three different panel widths. The results showed that the AoD and $S_{\max }$ considerably decreased with decreasing the panel width. This happened because once the panel width was reduced, the extraction area in underground was also reduced, resulted in decreasing of the extraction area to mining depth ratio. Therefore, the overburden strata were more able to bridge across the mined-out area, then the AoD and $S_{\max }$ were reduced, and resulted in a flat and shallow subsidence profile. From the simulated results, when compared the results of the $100 \mathrm{~m}$ and $70 \mathrm{~m}$ panel widths to the $130 \mathrm{~m}$ panel width, the AoD decreased from $55^{\circ}$ to $50^{\circ}$ and $34^{\circ}$, while the $\mathrm{S}_{\max }$ reduced from $63.33 \%$ to $12.82 \%$ and $4.73 \%$ of the total extracted seam height, respectively.

\subsection{Influence of of Pillar Width on Characteristics of Surface Subsidence}

For a better understanding of surface subsidence characteristics, the influence of pillar width was likewise studied in this paper. The simulations were made for four pillar widths such as $30 \mathrm{~m}, 40 \mathrm{~m}, 50 \mathrm{~m}$, and $60 \mathrm{~m}$. Three longwall panels of $130 \mathrm{~m}$ width and the mining depth of $200 \mathrm{~m}$, were considered in the simulations. From the simulated results (Figure 10), the AoD and $\mathrm{S}_{\max }$ tended to reduce as the pillar width increased. This was due to an increase in the pillar width to mining depth ratio. Compared to the $30 \mathrm{~m}$ pillar width, the AoD decreased from $55^{\circ}$ to $54^{\circ}$ in case of $60 \mathrm{~m}$ pillar width. However, in cases of the $40 \mathrm{~m}$ and $50 \mathrm{~m}$ pillar widths, the AoD values remained constant as $55^{\circ}$. At the same time, the $S_{\max }$ slightly decreased from $63.33 \%$ to $56.57 \%, 50.97 \%$, and $47.90 \%$ of the total extracted seam thickness when the pillar width was $40 \mathrm{~m}, 50 \mathrm{~m}$, and $60 \mathrm{~m}$, respectively. According to the results, it is agreed that the magnitude of the AoD and $S_{\max }$ can be minimized not only by reducing the panel width, but also by increasing the pillar width. However, by decreasing the panel width or increasing the pillar width, the percentage of coal recovery will be reduced due to the coal extracting area is decreased, and the large coal pillars have to be left within the coal seam. For this reason, an alternative subsidence controlling method using the backfilling material was studied and discussed in the next section.

\subsection{Impact of Backfilling Material Application on Surface Subsidence Characteristics}

The impact of backfilling material was studied in a longwall mining at $200 \mathrm{~m}$ depth. Two types of backfills, such as non-cohesive and cohesive backfills, were simulated in the simulations. The longwall mining model included three panels of $130 \mathrm{~m}$ width. The size of coal pillar was $30 \mathrm{~m}$ in this case. The results of AoD and $\mathrm{S}_{\max }$ are illustrated in Figure 11. The simulated results indicated that the backfilling material had played an important role in reducing the $\mathrm{AoD}$ and $\mathrm{S}_{\max }$. The smaller $\mathrm{AoD}$ and $\mathrm{S}_{\max }$ were observed when a cohesive backfill was applied. This was due to the cohesive backfill gave higher strengths, and it provided stronger support to the overburden strata than that the non-cohesive backfill did. Compared the simulated results of mining with non-cohesive and cohesive backfills to mining with no backfill application, the AoD significantly decreased from $55^{\circ}$ to $45^{\circ}$ and $1^{\circ}$, respectively, while the $\mathrm{S}_{\max }$ largely reduced from $63.33 \%$ to $12.03 \%$ and $1.00 \%$ of the total extracted seam thickness, respectively.

\section{Conclusion}

Understanding of surface subsidence characteristics is beneficial to control the impacts of subsidence at the surface. The appropriate controlling methods can be anticipated if its characteristics are well understood. The characteristics of surface subsidence induced by longwall mining in poor ground conditions are investigated by means of numerical simulation techniques using FLAC3D software. According to the simulated results, 
following important findings can be concluded:

- In single panel mining, the AoD increases as the mining depth increases. In contrast, the largest extent of $\mathrm{S}_{\max }$ is found at the shallowest depth.

- When several panels are mined in a series, the magnitude of AoD and $\mathrm{S}_{\max }$ increases as the subsequent panels are mined. However, the increment of these two parameters, and the characteristics of subsidence profile, are significantly associated with the pillar width to mining depth ratio.
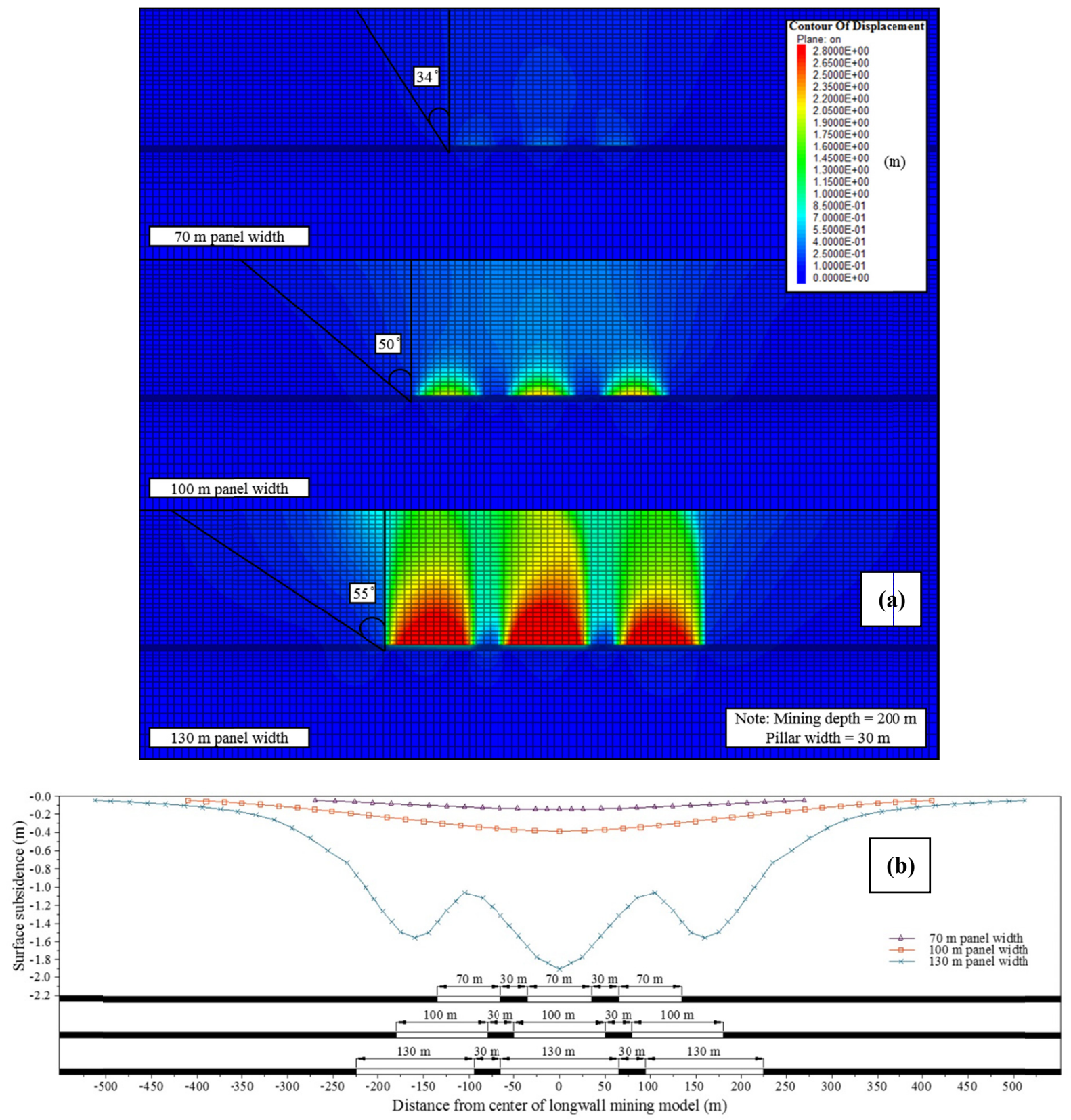

Figure 9. Results of surface subsidence simulation for effect of longwall panel width (a) contour of subsidence and angle of draw (b) profile of surface subsidence 


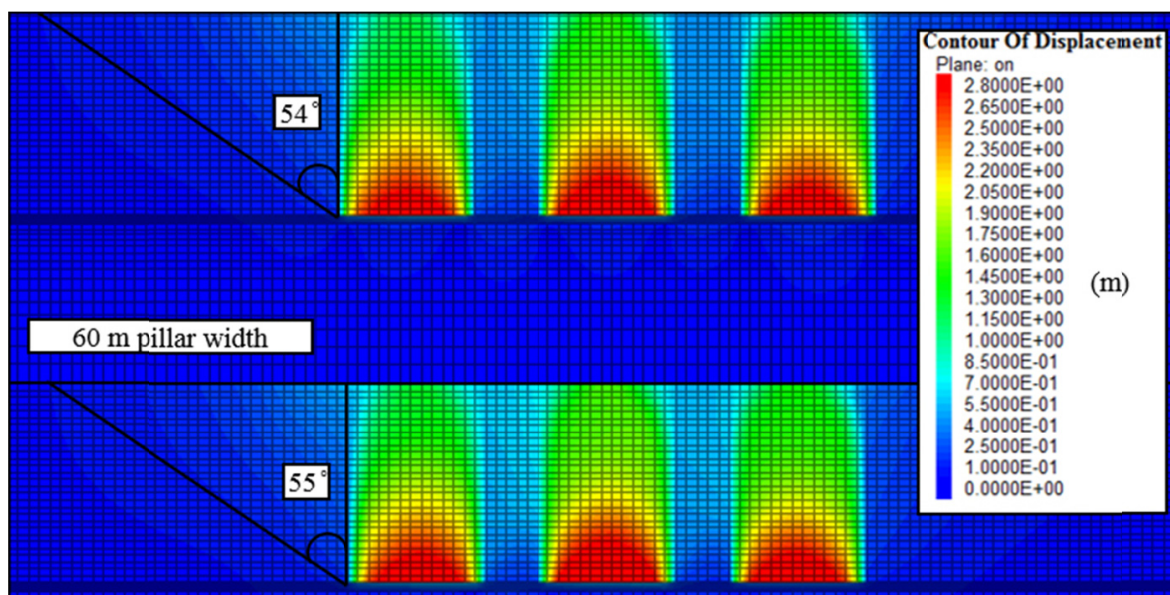

$50 \mathrm{~m}$ pillar width

$55^{\circ}$

(a)

$30 \mathrm{~m}$ pillar width

Note: Mining depth $=200 \mathrm{~m}$

Panel width $=130 \mathrm{~m}$

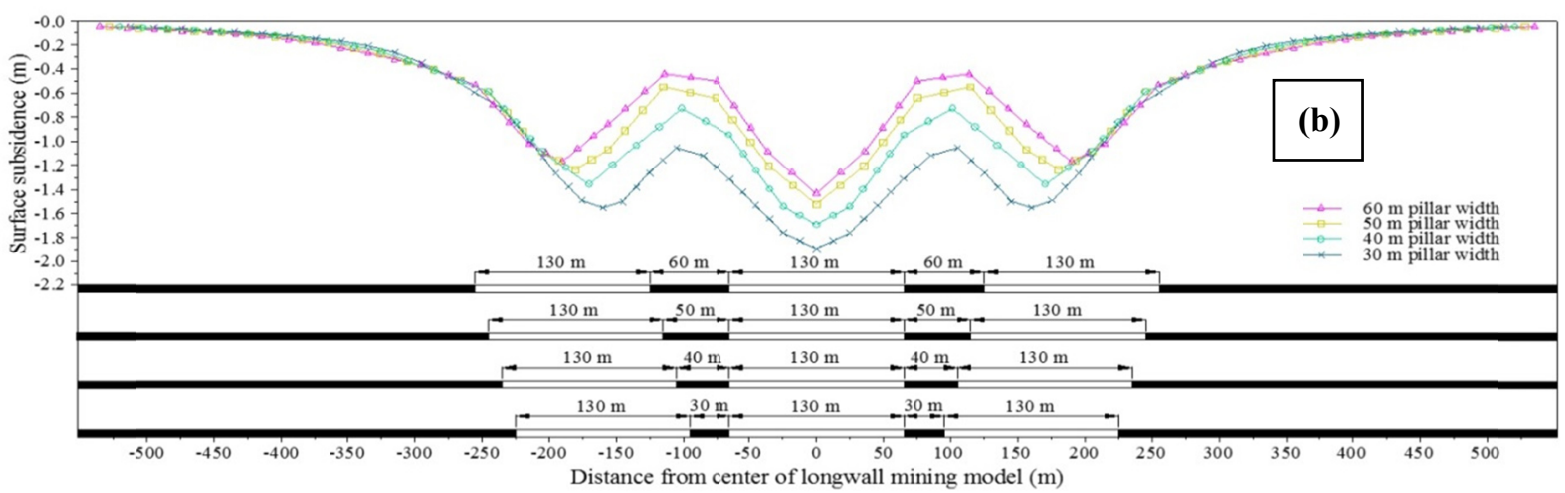

Figure 10. Results of surface subsidence simulation for influence of pillar width (a) contour of subsidence and angle of draw (b) profile of surface subsidence

- The width of a longwall panel is found to be a significant factor constraining the magnitude of AoD and $\mathrm{S}_{\max }$. The narrower panel width produces smaller AoD and $\mathrm{S}_{\max }$.

- By increasing the width of coal pillar, the value of $\mathrm{AoD}$ and $\mathrm{S}_{\max }$ can be minimized. The use of a larger pillar 
width results in smaller AoD and $\mathrm{S}_{\max }$.

- The use of backfilling material is very effective to control the AoD and $\mathrm{S}_{\max }$. The stronger backfill provides a better support to the overburden strata, and resulting in minor impacts at the surface.

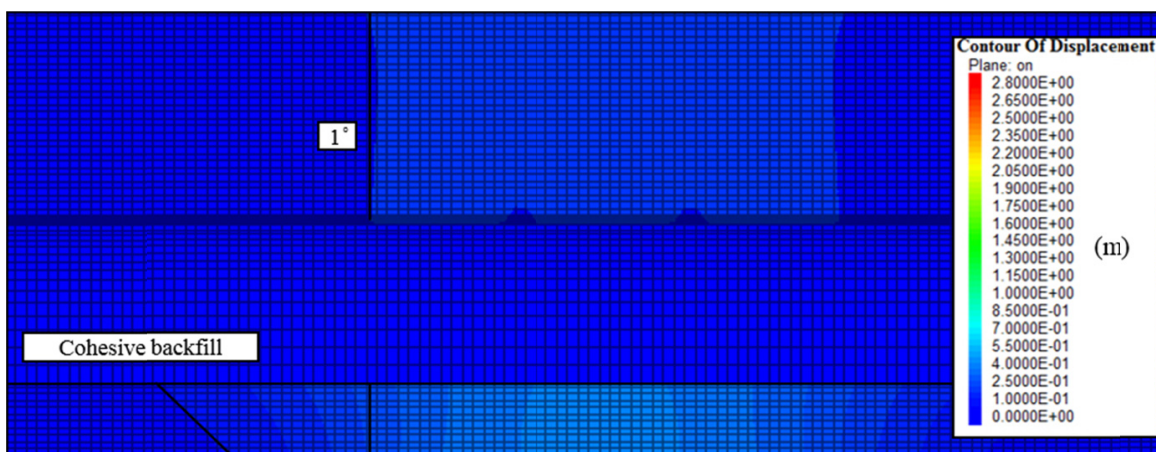

$45^{\circ}$

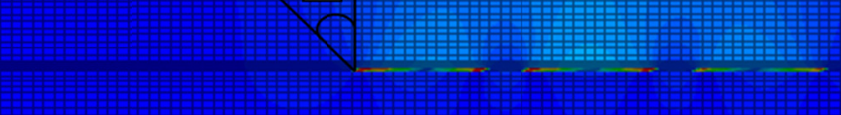

Non-cohesive backfill

$55^{\circ}$

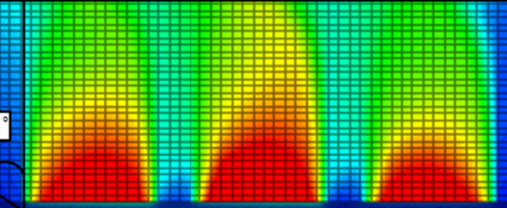

(a)

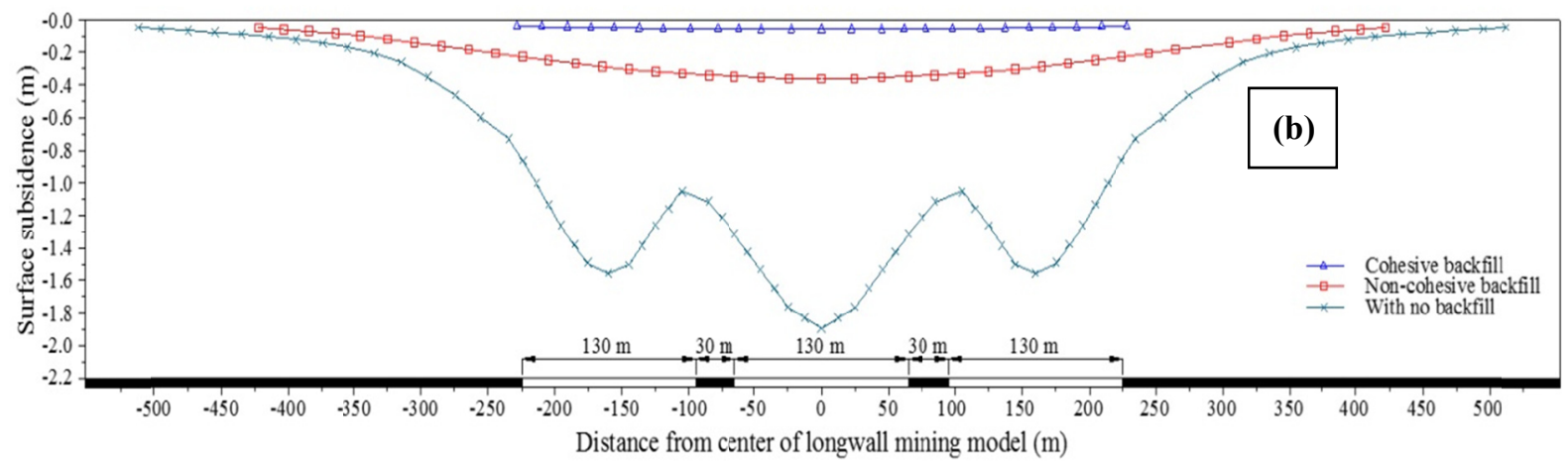

Figure 11. Results of surface subsidence simulation for impact of backfilling material application (a) contour of subsidence and angle of draw (b) profile of surface subsidence

\section{Acknowledgments}

The authors are grateful to the Laboratory of Rock Engineering and Mining Machinery, Department of Earth Resources Engineering, Faculty of Engineering, Kyushu University for all kinds of supports during conducting this research.

\section{References}

Brady, B. H. G., \& Brown, E. T. (2004). Rock mechanics for underground mining ( ${ }^{\text {rd }}$ Ed.). Dordrecht.

Choudhary, S. (2013). Some properties of fly ash for mine backfilling (Bachelor dissertation). National Institute 
of Technology, Rourkela, India. Retrieved from http://ethesis.nitrkl.ac.in/5235/1/109MN0591.pdf

Garcia, A., Altounyan, P., Nitaramorn, A., \& Lewis, A. (2010). Ground control aspects of a successful underground coal mine trial in weak strata in Indonesia. Proceeding of the $29^{\text {th }}$ International Conference on Ground Control in Mining, 1-9. from http://icgem.conferenceacademy.com/papers/detail.aspx?iid=306

Hoek, E. (2006). Practice rock engineering. North Vancouver, B. C., Canada V7R 4X1. Retrieved from https://www.rocscience.com/documents/hoek/corner/Practical-Rock-Engineering-Full-Text.pdf

Hoek, E., \& Brown, E. T. (1980). Underground excavations in rock. London, UK.

Hoek, E., Kaiser, P. K., \& Bawden, W. F. (1993). Support of underground excavations in hard rock. West Broadway Professional Centre, Vancouver, British Columbia. Retrieved from http://www.mirarco.org/wp-content/uploads/mirarco_books/Support_of_Underground_Excavations_in_Har d_Rock.pdf

IESC (Independent Expert Scientific Committee). (2015). Monitoring and management of subsidence induced by longwall coal mining activity. GPO Box 787 Canberra ACT 2601, Australia. Retrieved from https://www.environment.gov.au/system/files/resources/8a22c56a-3c83-4812-aa2f-9d0bc40ac718/files/mon itoring-management-subsidence-induced-longwall-coal-mining-activity.pdf

Indonesia-Investments. (2016). Coal in Indonesia. Retrieved from $\mathrm{http} / / / \mathrm{www}$.indonesia-investments.com/business/commodities/coal/item236

ITASCA Consulting Group, Inc. (2017, January 11). FLAC3D version 6.0 explicit continuum modeling of non-linear material behavior in 3D. Retrieved from http://www.itascacg.com/software/flac3d

Keilich, W., Seedsman, R. W., \& Aziz, N. (2006). Numerical modelling of mining induced subsidence. Coal Operators' Conference, University of Wollongong, Australia, 313-326. Retrieved from http://ro.uow.edu.au/cgi/viewcontent.cgi?article=1057\& context=coal

MSEC (Mine Subsidence Engineering Consultants). (2007). Introduction to longwall mining and subsidence. PO Box 3047 Willoughby North NSW 2068, Australia. Retrieved from http://www.minesubsidence.com/index_files/files/General_Disc_Mine_Subs_Ground_Mvmnts.pdf

Peng, S. S., \& Chiang, H. S. (1984). Longwall mining. John Wiley \& Sons, New York.

PTGDM (PT Gerbang Daya Mandiri Underground Mine Project). (2010). Geology and deposit condition (Unpublished report). The Feasibility Study of PT GDM Underground Coal Mine, Indonesia.

Sasaoka, T., Shimada, H., Hamanaka, A., Sulistianto, B., Ichinose, M., \& Matsui, K. (2015a). Geotechnical issues on application of highwall mining system in Indonesia. Vietrock 2015 an ISRM Specialized Conference, Hanoi, Vietnam. Retrieved from http://vietrocknet.org/app/webroot/img/files/Vietrock2015\%20Proceedings/S072.pdf

Sasaoka, T., Shimada, H., Ichinose, M., Matsui, K., Kramadibrata, S., Sulistianto, B., \& Watinena, R. (2007). Improvement of roof support system at a new underground coal developed from open-cut highwall in Indonesia. Proceeding of the $26^{\text {th }}$ International Conference on Ground Control in Mining, 122-128. Retrieved from http://icgcm.conferenceacademy.com/papers/detail.aspx?subdomain=icgcm\&iid=398

Sasaoka, T., Shimada, H., Zarlin, N., Takamoto, H., Matsui, K., Kramadibrata, S., \& Sulistianto, B. (2014). Geotechnical issues in the application of rock bolting technology for the development of underground coal mines in Indonesia. International Journal of Mining, Reclamation and Environment, 28(3), 150-172. http://dx.doi.org/10.1080/17480930.2013.804258

Sasaoka, T., Takamoto, H., Shimada, H., Oya, J., Hamanaka, A., \& Matsui, K. (2015b). Surface subsidence due to underground mining operation under weak geological in Indonesia. International Journal of Rock Mechanics and Geotechnical Engineering, 7(3), 337-344. http://dx.doi.org/10.1016/j.jrmge.2015.01.007

Takamoto, H., Sasaoka, T., H., Shimada, H., Oya, J., Hamanaka, A., \& Matsui, K. (2014). Study on surface subsidence due to longwall mining operation under weak geological condition in Indonesia. Proceeding of the Chinese International Conference on Ground Control in Mining, China, 177-182. Retrieved from http://icgcm.conferenceacademy.com/papers/otherdetail.aspx?otherbookid=3\&iid=2464

Thin, I. G. T., Pine, R. J., \& Trueman, R. (1993). Numerical modelling as an aid to the determination of the stress distribution in the goaf due to longwall coal mining. International Journal of Rock Mechanics and Mining Sciences and Geomechanics Abstracts, 30(7), 1403-1409. http://dx.doi.org/10.1016/0148-9062(93)90128-Z 
Wang, H., Poulsen, B. A., Shen, B., Xue, S., \& Jiang, Y. (2011). The influence of roadway backfill on the coal pillar strength by numerical investigation. Journal of Rock Mechanics and Mining Sciences, 48(3), 443-450. http://dx.doi.org/10.1016/j.jirmms.2010.09.007

Whittaker, B. N., \& Reddish, D. J. (1989). Subsidence: Occurrence, prediction and control. Amsterdam, The Netherlands.

Xie, H., Chen, Z., \& Wang, J. (1999). Three-dimensional numerical analysis of deformation and failure during top coal caving. International Journal of Rock Mechanics and Mining Sciences, 36(5), 651-658. http://dx.doi.org/10.1016/S0148-9062(99)00027-3

Xu, N., Kulatilake, P. H. S. W., Tian, H., Wu, X., Nan, Y., \& Wei, T. (2013). Surface subsidence prediction for WUTONG mine using a 3-D finite difference method. Journal of Computers and Geotechnics, 48, 134-145. http://dx.doi.org/10.1016/j.compgeo.2012.09.014

Yasiti, N. E., \& Unver, B. (2005). 3D numerical modeling of longwall mining with top-coal caving. International Journal of Rock Mechanics and Mining Sciences, 42(2), 219-235. http://dx.doi.org/10.1016/j.jirmms.2004.08.007

Zhang, C., Mitra, R., \& Hebblewhite, B. (2006). Numerical modeling of mining subsidence in the Southern Coalfield of New South Wales, Australia. FLAC/DEM Syposium, An Itasca International Company. Retrieved from http://www.itascacg.com/sites/itascacg.com/files/documents/01-06.pdf

\section{Copyrights}

Copyright for this article is retained by the author(s), with first publication rights granted to the journal.

This is an open-access article distributed under the terms and conditions of the Creative Commons Attribution license (http://creativecommons.org/licenses/by/4.0/). 